\title{
MIĘDZYNARODOWA WSPÓŁPRACA ORGANIZACJI PRZEPROWADZAJĄCYCH NIEZALEŻNE PORÓWNAWCZE TESTY PRODUKTÓW
}

\begin{abstract}
WSTĘP
Pierwsza organizacja testująca produkty ${ }^{1}$ na użytek konsumentów - Consumers' Research Inc. ${ }^{2}$ - powstała w 1927 roku w Stanach Zjednoczonych ${ }^{3}$. Dzięki wsparciu finansowemu kilku liberalnych czasopism przeprowadzała ona testy produktów, których wyniki rozpowszechniała za pomocą czasopisma „Consumers' Research Bulletin”. W wyniku wewnętrznych nieporozumień w lutym 1936 roku wyodrębniła się z niej nowa organizacja Consumers Union (CU), która wyniki przeprowadzonych testów publikowała w czasopiśmie „Consumer Reports”. W ciągu kilku lat Consumers Union stała się główną instytucją konsumencką w Stanach Zjednoczonych ${ }^{5}$.

Po zakończeniu II wojny światowej - w latach 50. XX wieku - organizacje zajmujące się przeprowadzaniem niezależnych porównawczych testów produktów ${ }^{6}$ zaczęły powstawać w Europie Zachodniej - przykładowo: w 1951 roku we

* Stypendystka w ramach projektu „Weź stypendium - dla rozwoju” współfinansowanego ze środków Europejskiego Funduszu Społecznego w ramach Programu Operacyjnego Kapitał Ludzki 2007-2013.

1 Pojęcie produktów obejmuje również usługi.

2 Do 1929 roku działała pod nazwą Consumers' Club.

3 Szerzej na temat powstania organizacji: R. Mayer, The consumer movement. Guardians of the marketplace, Twayne Publishers, Boston 1989, s. 20-21.

4 Początkowo zwane Consumers Union Reports.

5 R. Mayer, op. cit., s. 43.

6 Niezależne porównawcze testy produktów obejmują sprawdzanie i ocenę cech określonych produktów, mających takie samo zastosowanie, pod kątem ich przydatności użytkowej; Leitfaden für die Sachverständigen der Industrie bei der Stiftung Warentest, Anhang I DIN-Norm 66052 „Warentest Begriff", Bundesverband der Deutschen Industrie e.V., September 2003.
\end{abstract}


Francji (Union Fédérale des Consommateurs-Que Choisir ${ }^{7}$ ), w 1953 roku w Holandii (Consumentenbond), w 1957 roku w Wielkiej Brytanii (Consumers' Association Which?) i w Belgii (Association Belge des Consommateurs Test-Achats), a w $1964^{8}$ roku w Niemczech (Stiftung Warentest) - oraz poza Europa m.in. w 1959 roku w Nowej Zelandii (Consumer New Zealand), w 1960 roku w Australii (Australian Consumers' Association-Choice), a w 1974 roku w Hongkongu (HongKong Consumer Council). Ich powstawanie było odpowiedzią m.in. na rosnącą różnorodność i zaawansowanie technologiczne produktów dostępnych na rynku, rozwój mało informacyjnej reklamy oraz malejącą rolę sprzedawcy jako doradcy w sprawie zakupu - ze względu na jego ograniczoną wiedzę o szerokiej ofercie handlowej. W przypadku coraz większej liczby produktów konsumenci nie byli w stanie sami ocenić ich jakości, funkcjonalności i relacji ceny do jakości przed dokonaniem zakupu - wyniki niezależnych porównawczych testów produktów, publikowane w przystępnej formie w czasopismach konsumenckich, miały im ułatwić wybór odpowiedniego produktu i dzięki temu zwiększyć transparentność na rynku.

\section{PRZYCZYNY MIĘDZYNARODOWEJ WSPÓŁPRACY ORGANIZACJ PRZEPROWADZAJĄCYCH NIEZALEŻNE PORÓWNAWCZE TESTY PRODUKTÓW}

Już na początku lat 60.XX wieku organizacje z różnych krajów, przeprowadzające niezależne porównawcze testy produktów, nawiązały współpracę. Dzięki wspólnemu przeprowadzaniu testów korzystały one z efektu synergii, co pozwalało im obniżyć koszty testowania produktów, a w rezultacie uwzględnić w testach produkty większej liczby producentów. Wraz z rozwojem wspólnego rynku w Europie i procesów globalizacji przeprowadzanie porównawczych testów produktów zyskiwało na znaczeniu ze względu na następujące czynniki: coraz szerszy asortyment produktów, dostępność tych samych produktów na coraz większej liczbie rynków krajowych, rosnącą mobilność konsumentów w skali międzynarodowej oraz rozwój Internetu i handlu elektronicznego. Do wspólnego przeprowadzania testów w skali międzynarodowej skłaniało również rosnące skomplikowanie technologiczne produktów, które powodowało konieczność uwzględniania coraz większej liczby parametrów przy testowaniu produktów i w efekcie podrażało cały proces. Obniżenie kosztów testowania produktów dzięki współpracy międzyna-

\footnotetext{
Pierwotna nazwa: Union Fédérale de la Consommation.

8 W latach 50. XX wieku testy sporadycznie przeprowadzane byly przez Arbeitsgemeinschaft der Verbraucherverbände. Szerzej: G. Silberer, Warentest, Informationsmarketing, Verbraucherverhalten. Die Verbreitung von Gütertestinformationen und deren Verwendung im Konsumentenbereich, Nicolaische Verlagsbuchhandlung, Berlin 1979, s. 61-81.
} 
rodowej umożliwiło nowo powstałym organizacjom szybszy rozwój, a organizacjom mniejszym, dysponującym ograniczonymi zasobami finansowymi, publikację wyników testów na szerszą skalę.

Międzynarodowa współpraca w obszarze testowania produktów była prowadzona również w celu promocji takiej działalności, a także wymiany doświadczeń i informacji dotyczących: metod testowania, sposobów przedstawiania wyników testów w publikacjach, niezależnych laboratoriów testujących poszczególne rodzaje produktów oraz uzyskania dostępu do wyników testów i publikacji autorstwa innych organizacji. Aby ułatwić wykorzystanie wyników testów przeprowadzonych przez organizację z innego państwa oraz zwiększyć wiarygodność przeprowadzanych testów, organizacje podejmowały wspólpracę w zakresie standaryzowania metod i programów testów oraz międzynarodowej promocji standaryzacji norm technicznych dla poszczególnych produktów.

\section{MIĘDZYNARODOWA WSPÓtPRACA DWU-I WIELOSTRONNA W ZAKRESIE PRZEPROWADZANIA NIEZALEŻNYCH PORÓWNAWCZYCH TESTÓW PRODUKTÓW}

\section{INTERNATIONAL ORGANIZATION OF CONSUMERS UNIONS (IOCU)}

W 1960 roku pięć organizacji - Consumers Union (CU, Stany Zjednoczone), Consumers' Association Which? (CA, Wielka Brytania), Consumentenbond (Holandia), Union Belge des Consommateurs-Tests Achats (Belgia) i Australian Consumers' Association-Choice (Australia) - założyło International Organization of Consumers Unions (IOCU) ${ }^{9}$, która miała służyć jako platforma kontaktu między organizacjami członkowskimi w obszarze porównawczych testów produktów. W latach 1960-1968 do zadań IOCU należały m.in.: wymiana informacji na temat metod przeprowadzania testów i publikacji wydawanych przez organizacje konsumenckie; utworzenie katalogu niezależnych laboratoriów testujących poszczególne produkty w różnych krajach; promowanie międzynarodowej współpracy w obszarze porównawczych testów produktów; organizowanie międzynarodowych spotkań w celu promocji takich testów oraz określanie zasad użycia wyników testów i przedruków innych materiałów opublikowanych przez organizacje członkowskie ${ }^{10}$. IOCU wydawała regularnie „Testbulletin”, który zawierał informacje na temat działalności organizacji członkowskich oraz poruszał

9 Pierwotna nazwa: International Office of Consumers Unions; w 1995 roku organizacja zmieniła nazwę na Consumers International.

10 H. Thorelli, S. Thorelli, Consumer Information Handbook: Europe and North America, Preager Publishers, New York 1975, s. 481. 
problemy związane $\mathrm{z}$ przeprowadzaniem porównawczych testów produktów ${ }^{11}$. Sporadycznie, za pomocą Research Committee (Komitetu Badań), IOCU koordynowała również przeprowadzanie międzynarodowych testów produktów, wykonywanych w praktyce przez jedną organizację członkowską, np. w latach 1960-1962 Consumers' Association wykonała międzynarodowy test męskich zegarków na rękę. Research Committee odpowiadał również za kontakty z Eurotest Committee europejskiej organizacji Bureau Européen des Unions de Consommateurs $^{12}$ (BEUC).

W 1968 roku IOCU przyjęła nowy statut, który zniósł wymóg regularnego przeprowadzania niezależnych porównawczych testów produktów i publikowania ich wyników dla zostania członkiem tej organizacji. Od przyjęcia nowego statutu IOCU zajmowała się szerokim zakresem spraw konsumenckich - promocja międzynarodowej współpracy w obszarze porównawczych testów produktów była tylko jednym z ośmiu statutowych celów organizacji. Spowodowało to coraz mniejszą aktywność IOCU w tym obszarze, ograniczającą się do sporadycznej wymiany informacji i doświadczeń ${ }^{13}$.

\section{BUREAU EUROPÉEN DES UNIONS DE CONSOMMATEURS (BEUC) - EUROTESTY}

W 1962 roku w Brukseli organizacje konsumenckie z państw członkowskich ${ }^{14}$ ówczesnej Europejskiej Wspólnoty Gospodarczej (EWG) utworzyły organizację Bureau Européen des Unions de Consommateurs (BEUC), której zadaniem było lobbowanie za interesami konsumentów na forum EWG. Jeszcze w roku swojego powstania BEUC zainicjowała przeprowadzanie niezależnych porównawczych testów produktów (tzw. eurotestów) na poziomie międzynarodowym (EWG + Wielka Brytania). Zadaniem BEUC (dokładnie Eurotest Committee ${ }^{15}$ ) było

11 H. Brennecke, Der vergleichender Warentest. Eine Untersuchung seiner Möglichkeiten und Grenzen im Hinblick auf Marktübersicht des Verbrauchers, Dissertation zur Erlangung des wirtschaftswissenschaftlichen Doktorgrades des Rechts- und Staatswissenschaftlichen Fakultät der GeorgeAugust Uniwersität zu Göttingen, Göttingen 1964, s. 215.

12 Nazwa angielska: European Consumers' Organization.

13 Wśród ostatnich działań na większą skalę znalazły się m.in. projekt Joint Testing w 1974 roku, publikacja Consumer Testing and Research z 1976 roku oraz zalecenia dotyczące zasad przeprowadzania testów Guide to principles of comparative testing z 1985 roku.

14 Założyciele to: Association des Consommateurs i Union Féminine pour l'Information et la Défense du Consommateur z Belgii, Organisation Générale des Consommateurs i Union Fédérale de la Consommation z Francji, Arbeitsgemeinschaft der Verbraucherverbände z Niemiec, Unione Nazionale Consumatori z Włoch, Union Luxembourgeoise des Consommateurs z Luxemburga oraz Consumentenbond i Nederlandse Huishoudraad z Holandii; od początku z organizacją współpracowała również Consumers' Association z Wielkiej Brytanii.

15 Szerzej: Plan d’organisation des Euro-Tests, BEUC Assemblée Générale, Rome 24-25.05.1965. 
opracowanie programu testu, natomiast za samo przeprowadzenie go w niezależnym laboratorium odpowiadała jedna z organizacji członkowskich BEUC lub CA z Wielkiej Brytanii ${ }^{16}$. Zakładano realizację sześciu wspólnych testów w ciągu roku, z których wykonanie każdego miało trwać nie dłużej niż 6 miesięcy ${ }^{17}$. Każda organizacja członkowska oraz CA miały prawo przekazać próbki produktów do uwzględnienia w ramach wspólnych testów i rozpowszechniać ich wyniki w swoich publikacjach w rubryce „Euro-Test”. Ponadto spoczywał na niej obowiązek zapłacenia za przetestowanie przesłanych próbek. W przyszłości planowano publikację wyników testów we wspólnym czasopiśmie „Euro-Test”18. W 1964 roku Rada BEUC zaproponowała członkom wyodrębnienie finansowania eurotestów od innych obszarów działalności organizacji przez utworzenie specjalnego, oddzielnie administrowanego funduszu eurotestów w celu ubiegania się o pomoc finansową z EWG na ich prowadzenie ${ }^{19}$.

Eurotesty przeprowadzano w latach 1964-1965 (aspiryna, miksery ręczne, lampy przeciwmgielne i aparaty fotograficzne) oraz w 1968 roku (żelazka elektryczne).Ponadto planowano realizację wspólnych testów m.in. soków owocowych, baterii, golarek elektrycznych, past do zębów i kremów przeciwsłonecznych ${ }^{20}$. Nie zostały one jednak wykonane, gdyż idea eurotestów upadła, na co złożyło się kilka powodów. Główną przyczyną fiaska eurotestów w latach 60. XX wieku było duże zróżnicowanie produktów dostępnych na rynkach poszczególnych państw członkowskich EWG ze względu na niezakończoną budowę strefy wolnego handlu.

Przeprowadzanie wspólnych testów utrudniał również słaby rozwój międzynarodowych standardów technicznych dotyczących produktów, dlatego testując produkty, kierowano się normami krajowymi organizacji odpowiedzialnej za przeprowadzenie danego testu. Różne normy dla produktów w poszczególnych krajach zmniejszały przydatność uzyskanych wyników wspólnych testów. Dopracowania wymagał również sposób finansowania testów, gdyż podział kosztów między organizacje według liczby próbek wysłanych do wspólnego testu powodował, że organizacje, chcąc ograniczyć swoje wydatki, wstrzymywały się z wysyłaniem egzemplarzy produktów dostępnych w różnych krajach, licząc na to, że koszty testu poniesie inna organizacja ${ }^{21}$.

Brak sukcesu eurotestów można uzasadnić również słabym rozwojem i przygotowaniem organizacji członkowskich BEUC do ich wspólnego przeprowadza-

H. Thorelli, S. Thorelli, op. cit., s. 491.

17 Plan d'organisation des Euro-Tests, BEUC Assemblée Générale, Rome 24-25.05.1965.

18 H. Brennecke, op. cit., s. 213.

19 Dane uzyskane od Florence Punzano, Personal Assistant to the Director General in BEUC, 23.03.2011.

20 Ibidem.

21 H. Thorelli, S. Thorelli, op. cit., s. 492. 
nia. W większości były to organizacje młode, działające w tym obszarze dopiero od kilku lat i zmagające się z problemami finansowymi. Niektóre z nich tylko sporadycznie przeprowadzały porównawcze testy produktów. Efektem tego był brak odpowiedniego know-how. Do upadku eurotestów przyczyniły się również trudności wewnętrzne w samej organizacji BEUC.

Chociaż przeprowadzanie niezależnych porównawczych testów produktów na poziomie międzynarodowym nie powiodło się w latach 60 . XX wieku, próba wprowadzenia wówczas w życie tej idei wzbudza uznanie ${ }^{22}$. Niektóre $\mathrm{z}$ organizacji uczestniczących w eurotestach powróciły do wspólpracy w latach 70. XX wie$\mathrm{ku}$, natomiast sama BEUC nadal angażuje się w projekty dotyczące popularyzacji niezależnych porównawczych testów produktów (promocja, koordynacja, informowanie), ale nie przeprowadza ich już w praktyce.

\section{EUROPEJSKA WSPÓLNOTA GOSPODARCZA (UNIA EUROPEJSKA)}

Wstępną dyskusję na temat realizacji różnych projektów na poziomie EWG w obszarze porównawczych testów produktów, finansowanych przez Komisję Europejską (KE), rozpoczął z zainteresowanymi stronami jesienią 1969 roku EEC Special Service for Questions of Consumer Interest. Najbardziej ambitnym pomysłem tego organu było utworzenie europejskiego instytutu przeprowadzającego porównawcze testy produktów. Idea ta nie spotkała się jednak z poparciem organizacji przeprowadzających lub finansujących takie testy ${ }^{23}$. Miejsce dla wspólnotowych działań widziały one w obszarze harmonizacji metod i procedur testowania produktów.

Temat rozwoju niezależnych porównawczych testów produktów poruszany był również przez Komisję w programach ochrony konsumentów, uchwalanych od 1975 roku. W pierwszym takim programie Komisja zapowiedziała podjęcie kroków mających na celu zacieśnienie współpracy organizacji przeprowadzających porównawcze testy w państwach członkowskich EWG, polegającej w szczególności na wspólnym testowaniu produktów i ustalaniu podobnych standardów przeprowadzania testów ${ }^{24}$. Deklaracje poparcia dla takiej współpracy znalazły się również w kolejnych programach ochrony konsumentów.

Wsparcie Komisji dla rozwoju niezależnych porównawczych testów produktów nie ograniczało się tylko do słownych deklaracji - Komisja angażowała się

22 Ibidem, s. 491; J. Ruževičius, The influence of product quality comparative testing results on the market, „Ekonomika” 2005, nr 72, s. 122.

${ }_{23}$ H. Thorelli, S. Thorelli, op. cit., s. 501.

24 Preliminary programme of the European Economic Community for a consumer protection and information policy, OJ C 92 z 25.04.1975. 
również finansowo w realizację różnych projektów w tym obszarze. Przykładowo: w 1992 roku KE współfinansowała publikację - w 8 językach, w 13 krajach - specjalnego zeszytu „Aparaty fotograficzne i przenośne kamery wideo”, zawierającego wyniki wspólnego testu w ramach ICRT, a dwa lata później międzynarodowego zeszytu „Przewodnik po aparatach fotograficznych” (Euro-Camera-Guide $)^{25}$. Do innych projektów w obszarze niezależnych porównawczych testów produktów, które uzyskały wsparcie finansowe Komisji w ostatnich latach, należą: Transition Facility Programme Promoting Consumer Safety (seminaria Stiftung Warentest dla polskiej Inspekcji Handlowej na temat metod testowania produktów; II-XII.2008); Consumer Society and Citizens Network (we współpracy z Programem Narodów Zjednoczonych ds. Rozwoju - UNDP; beneficjent: Ukraina, 2006-2009) oraz Comparative Consumer Information on Financial Services (beneficjenci: Czechy, Polska, Słowacja, Węgry, Słowenia, Bułgaria, Rumunia; 2006-2009).

\section{INTERNATIONAL CONSUMER RESEARCH \& TESTING (ICRT)}

Mimo upadku idei eurotestów już w 1970 roku trzy organizacje przeprowadzające niezależne porównawcze testy produktów z państw należących do ówczesnej EWG (Stiftung Warentest z Niemiec, Consumentenbond z Holandii oraz Verbruikers Unie z Belgii) wykonały wspólnie test kuchenek elektrycznych. Był to początek stałej współpracy międzynarodowej w testowaniu produktów. Aby ułatwić planowanie czasowe testów i ujednolicić metodykę ich przeprowadzania, w 1973 roku założona została European Testing Group (ETG) ${ }^{26}$. W następnych latach zwiększała się zarówno liczba przeprowadzanych testów, jak również liczba organizacji współpracujących w ramach ETG, w tym spoza EWG. W 1990 roku współpraca w ramach ETG została zinstytucjonalizowana - powstała międzynarodowa organizacja International Consumer Research \& Testing $\left(\right.$ ICRT $\left.^{27}\right) \mathrm{z}$ siedzibą w Londynie, koordynująca współpracę w obszarze porównawczych testów produktów. Organizacje tworzące tzw. Nucleus Group w ETG - Stiftung Warentest z Niemiec, Consumentenbond z Holandii, Verbruikers Unie z Belgii oraz CA z Wielkiej Brytanii - weszły do zarządu ICRT. Obecnie stanowisko dyrektora w zarządzie posiadają również Union Fédérale des Consommateurs (Francja) oraz Consumers Union (USA).

25 H. D. Lösenbeck, Stiftung Warentest. Ein Rückblick 1964-2002, Stiftung Warentest, Berlin 2002, s. 139.

26 Ibidem, s. 137.

27 Do 1998 roku obowiązywał skrót IT. Zob.: H. D. Lösenbeck, op. cit., s. 138. 
Obecnie do ICRT należy 45 niezależnych organizacji z sześciu kontynentów - zarówno z krajów rozwiniętych, np. Choice z Australii i Stiftung Warentest z Niemiec, jak również z krajów rozwijających się, np. Right Choice India i Test z Ukrainy ${ }^{28}$. Zgodnie z artykułem 4a statutu ICRT jej członkiem może zostać każda organizacja przeprowadzająca porównawcze testy produktów wyłącznie w interesie konsumentów, która jest niezależna pod każdym względem od przedsiębiorców czy partii politycznych, nie finansuje swojej działalności z reklam, przeciwdziała wykorzystywaniu publikowanych przez siebie informacji w sposób wprowadzający w błąd oraz ma wystarczający potencjał do chociażby minimalnej aktywności w obszarze testów i publikacji ich wyników ${ }^{29}$.

Misją ICRT jest „wzmocnienie pozycji organizacji konsumenckich w przeprowadzaniu badań i testów w sposób efektywny pod względem finansowym" ${ }^{30}$. ICRT nie przeprowadza porównawczych testów produktów, a jedynie zajmuje się promocją i koordynacją współpracy pomiędzy organizacjami członkowskimi. Odpowiedzialność za przeprowadzanie testów ponoszą organizacje członkowskie - to one je finansują oraz publikują ich wyniki. Do zadań ICRT należą natomiast: ustalanie wytycznych i zasad współpracy (np. Guidelines for Comparative Joint Product Testing z 1992 roku), koordynacja planowania testów (prowadzenie banku danych z planowanymi datami przeprowadzenia określonych testów przez poszczególne organizacje członkowskie), arbitraż w przypadku konfliktów, sporządzanie listy kontaktów pracowników z organizacji członkowskich, organizacja i prowadzenie spotkań, zawieranie umów z laboratoriami, podział kosztów i ich fakturowanie oraz doskonalenie metodyki przeprowadzania testów ${ }^{31}$.

Istnieją trzy rodzaje członkostwa w ICRT w zależności od potencjału finansowego organizacji - typ A, B i C. Najwyższe opłaty ponoszone są za członkostwo typu A (ok. $115000 €^{32}$ ), a posiadające je organizacje wywierają największy wpływ na funkcjonowanie ICRT, gdyż każdej z nich przysługuje jedno stanowisko dyrektora w zarządzie (podejmowane są tu strategiczne decyzje) oraz sześć (tj. najwięcej) głosów w Zgromadzeniu Członków. Najmniejszy wpływ na funkcjonowanie ICRT (1 głos w Zgromadzeniu Członków) mają członkowie typu C

28 Pełna i aktualna lista organizacji członkowskich znajduje się na stronie: http://www.international-testing.org/About\%20ICRT/members.htm (data dostępu: 22.03.2011 r.).

29 Application for new membership of ICRT, dostępna na stronie: http://www.internationaltesting.org/About\%20ICRT/about.htm (data dostępu: 22.03 .2011 r.).

30 G. Adriaenssens, International Consumer Research E Testing, Belgrad 09.03.2009, prezentacja dostępna na stronie: http://ec.europa.eu/enlargement/taiex/dyn/create_speech.jsp? num=9005 (data dostępu: 27.03.2011 r.).

31 Ibidem.

32 Wywiad autorki z p. Heinzem Willnatem, kierownikiem Międzynarodowego Sekretariatu Stiftung Warentest, 22 kwietnia 2010 roku, Berlin. 
(np. Fundacja Pro-Test z Polski, Czech Association of Consumers TEST), którzy opłacają najniższe składki (ok. $2000 €)^{33}$.

Podczas dorocznego spotkania Zgromadzenia Członków ICRT następuje wybór tematów i ustalenie harmonogramu przyszłych testów, a ponadto opracowywane są jednolite metody testowania produktów oraz systemy ich oceny ${ }^{34}$. $\mathrm{Na}$ co dzień współpracę w tym obszarze koordynuje Management Committee (Komitet Zarządzający), wspomagany przez Sekretariat ICRT, w którym zatrudnionych jest 10 osób $^{35}$.

Pierwszym krokiem przy wspólnym przeprowadzaniu testów jest zaplanowanie terminu testu i ustalenie listy organizacji członkowskich, które chcą wziąć w nim udział. Podczas spotkania organizacje uczestniczące $\mathrm{w}$ teście wybierają spośród siebie tę, która będzie pełnić funkcję kierownika dla danego testu $(\mathrm{Su}-$ pervising Project Officer - SPO). Zadaniem organizacji przewodniczącej danemu testowi jest zorganizowanie jego przeprowadzenia w imieniu wszystkich zaangażowanych organizacji. Te ostatnie ustalają również wspólny program testu oraz wybierają laboratorium, które przetestuje produkty zgodnie $\mathrm{z}$ określonym wspólnym programem. Wybór produktów następuje na podstawie przeprowadzonej analizy rynku. We wspólnym teście, poza produktami badanymi wspólnie, może być na życzenie organizacji członkowskiej ICRT zbadany produkt, który występuje tylko na jej rynku, pod warunkiem że pokryje ona w pełni koszty jego przetestowania. SPO gromadzi uzyskane od innych organizacji produkty, które mają zostać sprawdzone, po czym wysyła je do laboratorium. Nadzoruje również proces testowania produktów w laboratorium, a na koniec otrzymuje raport z wynikami testu, który odpowiednio opracowuje. Wyniki testu omawiane są przez SPO podczas spotkania ze wszystkimi organizacjami uczestniczącymi w teście. Następnie są one publikowane w czasopismach poszczególnych organizacji. Ze względu na różnice kulturowo-socjologiczne między konsumentami w różnych krajach każda organizacja samodzielnie przygotowuje publikację dotyczącą wyników testów, zwracając uwagę na te wyniki testów, które z jej punktu widzenia są istotne $\mathrm{w}$ danym kraju ${ }^{36}$.

Każda organizacja ponosi koszty wspólnych testów w zależności od liczby produktów, których wyniki chce opublikować. Jeśli w ramach wspólnego testu pralek badanych jest 30 urządzeń, a dana organizacja chce opublikować wyniki dotyczące tylko 15 produktów, gdyż pozostałe nie są dostępne na rynku w jej kraju, wówczas uczestniczy we wspólfinansowaniu kosztów przeprowadzenia testu

\footnotetext{
33 Ibidem.

34 H. D. Lösenbeck, op. cit., s. 139.

35 G. Adriaenssens, op. cit.

36 Opis sposobu przeprowadzania wspólnych testów został sporządzony na podstawie danych uzyskanych podczas ww. rozmowy autorki z p. Heinzem Willnatem.
} 
tych 15 pralek. Ponadto przy podziale kosztów wspólnych testów uwzględniana jest wielkość nakładu czasopism danej organizacji członkowskiej ICRT lub liczba użytkowników, którzy zakupili dostęp do jej strony internetowej z wynikami testów. Przykładowo: dla Stiftung Warentest (członka typu A) współczynnik ponoszenia kosztów przy wspólnych testach wynosi 6,0, a dla Fundacji Pro-Test (członka typu C) przyjmuje on wartość $0,5^{37}$. W rezultacie małe organizacje płacą mniej za udział we wspólnych testach niż organizacje duże. Ze względu na wysokie koszty testowania produktów we wspólnych testach najczęściej uczestniczą organizacje typu A, do których przyłączają się organizacje typu B z jednym lub dwoma własnymi produktami. Organizacje typu C przeważnie publikują tylko wyniki wspólnych testów. Jeśli dana organizacja nie uczestniczyła w teście, może opublikować jego wyniki pod warunkiem uiszczenia odpowiedniej opłaty, zależnej od swojego statusu. Organizacje członkowskie typu C, ze względu na swój mały potencjał osobowy i finansowy, mają prawo do bezpłatnego opublikowania wyników $10-12^{38}$ wspólnych testów w ciągu roku ${ }^{39}$.Za publikację wyników każdego dodatkowego testu, w którym nie uczestniczyły, muszą uiścić opłatę w wysokości $1000 €^{40}$.

Rocznie w ramach ICRT organizacje członkowskie przeprowadzają ok. 40 dużych wspólnych testów i 150 tzw. małych wspólnych testów obejmujących m.in. opony zimowe, buty do biegania i farby do włosów. Ponadto w ciągu roku przeprowadzanych jest 10 tzw. testów ciągłych, polegających na regularnym testowaniu kolejnych modeli produktów, które podlegają szybkiemu postępowi technologicznemu. W ramach testów ciągłych badane są m.in.: cyfrowe aparaty fotograficzne, telefony komórkowe, telewizory, pralki i żarówki ${ }^{41}$. Rocznie testowanych jest ok. 5000 produktów, co kosztuje ok. $6 \mathrm{mln} €^{42}$. Wspólnym testom poddawane są przede wszystkim produkty gospodarstwa domowego i elektronika. W ramach wspólnych testów nie bada się jakości żywności, gdyż różnice w produktach sprzedawanych w poszczególnych krajach są zbyt duże.

Organizacja ICRT współpracuje również z innymi organizacjami, m.in. z UE i BEUC, w celu promocji porównawczych testów produktów. Przykładowo: w 1998 roku razem ze Stiftung Warentest i przy wsparciu finansowym Komisji Europejskiej zrealizowała projekt New Media and new Information Services

\footnotetext{
Ibidem.

Ibidem.

39 Liczą się tematy testów - jeśli w ciągu roku w ramach ICRT przeprowadzane są 2 testy danego produktu, np. ekspresów do kawy, ich publikacja przez członka typu C liczona jest jako

40 Ww. wywiad autorki z p. Heinzem Willnatem.

${ }^{41} \mathrm{http} / / /$ www.international-testing.org/About\%20ICRT/about.htm (data dostępu: 24.03.2011 r.).

42 G. Adriaenssens, op. cit.
} publikacja jednego testu. 
offered by Consumer Organizations, który dotyczył efektywnego wykorzystania nowych technik informacyjnych przez organizacje konsumenckie ${ }^{43}$, natomiast w 2006 roku wspólnie z BEUC i przy wsparciu finansowym Komisji Europejskiej ICRT zainicjowała projekt Capacity Building in Consumer Testing and Magazines in the New Member States, którego celem było utworzenie lub poprawa jakości czasopism i stron internetowych zawierających wyniki niezależnych porównawczych testów produktów w nowych państwach członkowskich UE, tak aby organizacje je wydające stały się członkami ICRT ${ }^{44}$.

\section{WSPÓŁPRACA BILATERALNA I NIESFORMALIZOWANA WSPÓtPRACA MULTILATERALNA}

Oprócz współpracy sformalizowanej na forum międzynarodowym kontynuowana jest współpraca bilateralna i niesformalizowana multilateralna. Najczęściej odbywa się ona pomiędzy organizacjami o ugruntowanej renomie w testowaniu produktów a podmiotami rozpoczynającymi działalność w tym obszarze, nienależącymi do ICRT. Dotyczy ona zazwyczaj wymiany doświadczeń, szkolenia pracowników czy zgody na przedruk wyników testów opublikowanych przez bardziej doświadczoną organizację - np.w 2009 roku Stiftung Warentest współpracowała z organizacjami konsumenckimi, m.in. z Rosji i Serbii, które wspierała w dalszej rozbudowie systemu informacji konsumenckiej; ponadto przyjęła wizyty przedstawicieli organizacji konsumenckich, m.in. z Chin, Japonii, Indonezji i Gruzji, którzy na miejscu chcieli poznać zasady jej funkcjonowania ${ }^{45}$.

\section{KORZYŚCI I OGRANICZENIA OBECNEJ WSPÓŁPRACY ORGANIZACJI PRZEPROWADZAJĄCYCH NIEZALEŻNE PORÓWNAWCZE TESTY PRODUKTÓW}

Podstawową korzyścią współpracy polegającej na wspólnym przeprowadzaniu testów są znacząco niższe koszty laboratoryjne. Już w przypadku wspólnego testowania produktów przez dwie organizacje koszty spadają o połowę. Im więcej

\footnotetext{
43 Szerzej: H.D. Lösenbeck, op. cit., s. 144.

44 Szerzej na temat projektu: A. Szarek, Polski konsument poinformowany?, „Prawo Europejskie w Praktyce" 2010, nr 5, s. 62-63; Questions and Answers on the promotion of independent consumer product testing, MEMO/09/371, Bruksela 03.09.2009, dokument dostępny na stronie: http://europa. eu/rapid/pressReleases Action.do?reference=MEMO/09/371\&format=HTML\&aged=0\&languag $\mathrm{e}=\mathrm{EN} \&$ guiLanguage $=e n$ (data dostępu: 27.03.2011 r.).

45 Jahresbericht 2009, Stiftung Warentest, Berlin 2010, s. 41.
} 
organizacji bierze udział w teście, tym koszty dla każdej z nich są niższe, co pozwala testować więcej produktów dostępnych na rynku. Ponadto w takim przypadku wydatki poniesione na zakup egzemplarzy do testowania dzielone są między większą liczbę podmiotów.

Poza korzyściami finansowymi wzajemna współpraca pozwala na wymianę doświadczeń w szeroko rozumianym obszarze porównawczych testów produktów - od ustalania metodyki realizacji testów do promocji ich wyników. Wymusza ona ujednolicanie w skali światowej zarówno norm dla produktów, jak i metod ich testowania.

W przypadku zlecania nadzoru nad przeprowadzeniem testu jednej organizacji, jak to jest w ICRT, oszczędzane są również zasoby ludzkie, tj. czas pracowników pozostałych organizacji uczestniczących we wspólnym teście.

Wspólne testowanie eliminuje również problem publikacji sprzecznych ze sobą wyników testów tego samego produktu. Jednocześnie, dzięki samodzielnemu opracowywaniu artykułów dotyczących uzyskanych wyników testów przez każdą organizację członkowską ICRT, możliwe jest ich dostosowanie do wymagań i cech krajowych konsumentów.

Dzięki członkostwu w ICRT organizacje z niskimi zasobami finansowymi, np. dopiero rozpoczynające działalność, mają dostęp do wyników testów drogich produktów, np. pralek, telewizorów i aparatów fotograficznych, których same nie byłyby w stanie sfinansować. Ponadto mogą one korzystać z doświadczeń dłużej funkcjonujących organizacji i dzięki temu zarówno uniknąć ich błędów, jak i wdrożyć ich dobre praktyki. Wspólne seminaria i szkolenia, również w ramach współpracy poza ICRT, zapewniają prawidłowe przeprowadzanie porównawczych testów, nawet przez nowo powstałe organizacje. Możliwość przedruku testów wykonanych przez inną organizację lub wzorowanie się na strukturze i szacie graficznej jej czasopisma wzbogaca ofertę organizacji niskobudżetowych.

Chociaż współpraca organizacji przeprowadzających niezależne porównawcze testy produktów trwa od lat 60 . XX wieku, są jeszcze obszary wymagające zmian. Pomimo wsparcia, również finansowego - udzielanego m.in. przez ICRT, UE i BEUC - w wielu krajach nie funkcjonują organizacje przeprowadzające niezależne porównawcze testy produktów lub działają, ale nie spełniają kryteriów przynależności do ICRT. Dotyczy to nie tylko krajów rozwijających się, ale również państw należących do UE, np. Litwy i Bułgarii. Oznacza to, że nawet na rynku wewnętrznym UE konsumenci nie mają równego dostępu do informacji na temat jakości produktów. W przypadku organizacji o członkostwie typu C w ICRT ich działalność ogranicza się zwykle do publikowania wyników wspólnych testów w ramach bezpłatnego limitu, jednak bez udziału w ich przeprowadzaniu. Wynika to $\mathrm{z}$ wysokich kosztów testowania produktów - np. przetestowanie w ramach wspólnego testu jednego proszku do prania, który występuje tylko na jednym 
rynku, kosztuje ok. 4000-5000 $€^{46}$, co dla członka typu C jest ceną zaporową. Skutkiem takiego stanu rzeczy jest deficyt informacji (po stronie konsumentów) o jakości produktów rodzimych wytwórców i dyskryminacja wytwórców produktów wysokiej jakości, którzy pozbawieni są bezpłatnej promocji w postaci wysokiej oceny w porównawczych testach produktów.

W porównaniu z liczbą organizacji członkowskich ICRT liczba wspólnych testów i przetestowanych produktów nie jest znacząca - ok. 200 testów i 5000 przetestowanych produktów. Te same wielkości w przypadku, np. Stiftung Warentest wynoszą odpowiednio ok. 300 i ok. 2100-250047. W wielu testach bierze udział tylko kilku członków ICRT (czasem tylko dwóch), najczęściej z jednego obszaru geograficznego. Jest to powodem relatywnie niedużej liczby przetestowanych produktów.

Co prawda opracowywanie wyników wspólnego testu na poziomie organizacji członkowskiej pozwala dostosować je do percepcji miejscowego konsumenta, lecz zarazem utrudnia korzystanie $z$ nich konsumentom zagranicznym. W poszczególnych organizacjach obowiązują różne zasady wykorzystywania wyników wspólnych testów do celów reklamowych przez przedsiębiorców - jedne dopuszczają, a inne zakazują takiej praktyki. Ponadto nie istnieje jedna internetowa baza wyników wszystkich wspólnych testów dostępna dla konsumentów.

Ograniczenia we wzajemnej współpracy organizacji, w szczególności w obszarze wspólnego testowania produktów, spowodowane są przede wszystkim brakiem środków finansowych na udział we wspólnych testach (zwłaszcza w małych organizacjach). Ponadto zróżnicowanie produktów dostępnych na poszczególnych rynkach utrudnia przeprowadzanie wspólnych testów; mowa zarówno o zróżnicowaniu fikcyjnym (np. różne nazywanie tych samych produktów), jak i faktycznym (np. sprzedaż różnych modeli).

\section{ZAKOŃCZENIE}

Biorąc pod uwagę zmiany, które nabrały tempa w ostatnich latach, tzn. postęp technologiczny, upowszechnienie Internetu i mobilność konsumentów, warte rozważenia są następujące propozycje w zakresie zintensyfikowania współpracy między organizacjami przeprowadzającymi niezależne porównawcze testy produktów:

\footnotetext{
46 Ww. wywiad autorki z p. Heinzem Willnatem.

47 W 2009 roku 305 testów (w 2008 roku 282), w ramach których zbadano 2116 produktów (w 2008 roku 2411); Jahresbericht 2009, Stiftung Warentest, Berlin 2010, s. 9.
} 
- umożliwienie członkom typu C w ICRT bezpłatnego przetestowania ograniczonej liczby, np. 10-12 produktów rodzimych wytwórców w ramach wspólnych testów w ciągu roku,

- zwiększenie liczby wspólnych testów przeprowadzanych w ramach ICRT, w tym objęcie nimi również żywności (np. napojów, słodyczy) oraz wybranych usług,

- zaangażowanie większej liczby organizacji członkowskich ICRT w przeprowadzanie wspólnych testów w celu poprawienia efektywności kosztowej,

- zwiększenie liczby testów ciągłych przeprowadzanych w ramach ICRT i objęcie nimi również np. wybranych kosmetyków czy obuwia,

- znalezienie nowych źródeł finansowania współpracy (w tym wspólnych testów) uzupełniających zaangażowanie finansowe organizacji biorących w niej udział, np. dotacje państwowe, dotacje $\mathrm{z}$ budżetu unijnego,

- uruchomienie strony internetowej ICRT (początkowo w języku angielskim), dostępnej dla konsumentów, na której zamieszczane byłyby wyniki wspólnych testów w ujęciu tabelarycznym (oraz wyszukiwarka),

- zwiększenie zatrudnienia w sekretariacie ICRT w celu zapewnienia obsługi strony internetowej,

- ujednolicenie zasad wykorzystywania wyników testów przez przedsiębiorców w celach reklamowych na poziomie ICRT i ewentualnie opracowanie wspólnego znaku jakości,

- zintensyfikowanie współpracy na poziomie UE ze względu na rynek wewnętrzny - zapewnienie konsumentom ze wszystkich państw członkowskich UE dostępu do wyników niezależnych porównawczych testów produktów, np. prowadzenie wspólnych testów unijnych.

Dzięki wdrożeniu przynajmniej części powyższych zaleceń, czyli nasileniu procesów integracyjnych wśród organizacji przeprowadzających niezależne porównawcze testy produktów, konsumenci uzyskają szerszy dostęp do informacji na temat jakości produktów. W różnych częściach świata będą promowane produkty uczciwych przedsiębiorców, a producenci dóbr niskiej jakości zostaną zmuszeni do konfrontacji z obiektywną informacją na temat ich produktów.

\section{BIBLIOGRAFIA}

Adriaenssens G., International Consumer Research E Testing, Belgrad 09.03.2009, prezentacja dostępna na stronie: http://ec.europa.eu/enlargement/taiex/dyn/create_speech. jsp?num=9005 (data dostępu: 27.03.2011 r.).

Brennecke H., Der vergleichender Warentest. Eine Untersuchung seiner Möglichkeiten und Grenzen im Hinblick auf Marktübersicht des Verbrauchers, Dissertation zur Erlangung 
des wirtschaftswissenschaftlichen Doktorgrades des Rechts- und Staatswissenschaft-

lichen Fakultät der George-August Universität zu Göttingen, Göttingen 1964.

http://www.international-testing.org/About\%20ICRT/about.htm (data dostępu: 22.03.2011 r.).

http://www.international-testing.org/About\%20ICRT/members.htm (data dostępu: 22.03.2011 r.).

Jahresbericht 2009, Stiftung Warentest, Berlin 2010.

Leitfaden für die Sachverständigen der Industrie bei der Stiftung Warentest, Anhang I DINNorm 66052 „Warentest Begriff”, Bundesverband der Deutschen Industrie e.V., September 2003.

Lösenbeck H. D., Stiftung Warentest. Ein Rückblick 1964-2002, Stiftung Warentest, Berlin 2002.

Mayer R., The consumer movement. Guardians of the marketplace, Twayne Publishers, Boston 1989.

Plan d'organisation des Euro-Tests, BEUC Assemblée Générale, Rome 24-25.05.1965.

Preliminary programme of the European Economic Community for a consumer protection and information policy, OJ C 92 z 25.04.1975.

Questions and Answers on the promotion of independent consumer product testing, MEMO/09/371, Bruksela 03.09.2009, dokument dostępny na stronie: http://europa. $\mathrm{eu} / \mathrm{rapid} /$ pressReleasesAction.do? reference=MEMO/09/371\&format=HTML\&ag ed $=0 \&$ language $=E N \&$ guiLanguage $=$ en (data dostępu: 27.03.2011 r.).

Ruževičius J., The influence of product quality comparative testing results on the market, „Ekonomika” 2005, nr 72.

Silberer G., Warentest, Informationsmarketing, Verbraucherverhalten. Die Verbreitung von Gütertestinformationen und deren Verwendung im Konsumentenbereich, Nicolaische Verlagsbuchhandlung, Berlin 1979.

Szarek A., Polski konsument poinformowany?, „Prawo Europejskie w Praktyce” 2010, nr 5. Thorelli H., Thorelli S., Consumer Information Handbook: Europe and North America, Preager Publishers, New York 1975.

\section{INTERNATIONAL COOPERATION BETWEEN ORGANIZATIONS CONDUCTING INDEPENDENT COMPARATIVE PRODUCT TESTS}

SUMMARY

The paper aims at analysing the fields and the rules of international cooperation between organizations conducting independent comparative product tests. It identifies the benefits and limitations of this cooperation. As a result, it formulates a set of recommendations regarding further integration of these organizations in the days of globalization and dissemination of the Internet. 
